\section{Pengaruh Kepercayaan, Kegunaan, Keamanan Terhadap Minat Menggunakan Mobile Payment Linkaja Dengan Kemudahan Sebagai Variable Mediasi}

\author{
(Studi pada Mahasiwa di Yogyakarta)
}

\author{
Mala Kresisiana Utami \\ Fakultas Ekonomi dan Bisnis Universitas Pembangunana Nasional \\ "Veteran" Yogyakarta \\ Email:malakresisiana12@gmail.com
}

The intention to use

LinkAja mobile payments

\begin{abstract}
This study aims to determine and analyze the effect of trust, usefulness, security and convenience as a mediating variable on the intention to use LinkAja mobile payments. This research is a survey research, where the research instrument is a questionnaire. The population in this study were the users of the LinkAja mobile application among students in Yogyakarta. Data collection was carried out in January. A sample of 225 respondents who were determined by purposive sampling technique. The data analysis technique used Partial Least Square (PLS). The results of the study found that: Trust has a positive and significant effect on intention to use. Usefulness has a positive and significant effect on intention to use. Security has a positive and significant effect on intention to use. Ease has a positive and significant effect on intention to use. Trust has a positive and significant effect on intention to use through ease. Usefulness has a positive and significant effect on intention to use through ease. Security has a positive and significant effect on intention to use through ease.
\end{abstract}

Key words: Trust, Usefulness, Security, Ease, And Intention to Use

\begin{abstract}
ABSTRAK
Penelitian ini bertujuan untuk mengetahui dan menganalisis pengaruh kepercayaan, kegunaan, keamanan dan kemudahan sebagai variable mediasi terhadap minat menggunakan mobile payment LinkAja. Penelitian ini dikategorikan sebagai penelitian survei, dimana instrumen penelitian ini berupa kuesioner. Populasi dalam penelitian ini adalah pengguna aplikasi mobile LinkAja pada mahasiswa di Yogyakarta. Pengambilan data dilakukan pada bulan Januari. Sampel sebanyak 225 responden yang ditentukan dengan teknik purposive sampling. Teknik analisis data menggunakan Partial Least Square(PLS). Hasil penelitian menemukan bahwa:Kepercayaan berpengaruh positif dan signifikan terhadap minat menggunakan. Kegunaan berpengaruh positif dan signifikan terhadap minat menggunakan. Keamanan berpengaruh positif dan signifikan terhadap minat menggunakan. Kemudahan berpengaruh positif dan signifikan terhadap minat menggunakan. Kepercayaan berpengaruh positif dan signifikan terhadap minat menggunakan melalui kemudahan. Kegunaan berpengaruh positif dan signifikan terhadap minat menggunakan melalui kemudahan. Keamanan berpengaruh positif dan signifikan terhadap minat menggunakan melalui kemudahan.
\end{abstract}

Kata kunci: Kepercayaan, Kegunaan, Keamanan, Kemudahan, dan Minat Menggunakan

\title{
PENDAHULUAN
}

\section{A. Latar Belakang}

Perkembangan industri perdagangan elektronik atau e-commerce, khususnya di Indonesia semakin memacu persaingan antara pelaku bisnis di dunia maya. Perkembangan bisnis online ini didukung oleh peningkatan secara signifikan dari

\section{JIMKES}

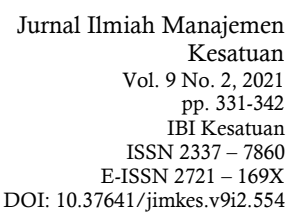


The intention to use LinkAja mobile payments

pengguna internet itu sendiri. Hal itu menyebabkan banyak pelaku bisnis yang tertarik untuk melakukan bisnis online dengan melihat pangsa pasar yang ada. Berdasarkan laporan dari MDI Ventures dan Mandiri Sekuritas Research bahwa munculnya mpayment sudah ada sejak 2007. Dimana salah satunya pertama kali dibuat adalah $T$ Cash. PT. Telekomunikasi Indonesia (Telkomsel) yang resmi diluncurkan pada 27 November 2007. T-Cash memberi berbagai kemudahan bagi para penggunanya, yaitu mudah dalam mengisi saldo, mudah dalam melakukan pembayaran di berbagai merchant yang bermitra dengan Telkomsel. Jadi tidak perlu repot membawa uang tunai saat berbelanja dan mempersingkat dalam pembayaran ditempat.

Pada tanggal 22 Februari 2019 T-Cash resmi berganti nama menjadi LinkAja. LinkAja merupakan mobile payment sinergi dari T-Cash dengan layanan keuangan elektronik berbagai Badan Usaha Milik negara (BUMN) seperti Bank Mandiri, Bank BNI, dan Bank BRI. Tujuan dari adanya sinergitas tersebut adalah untuk menghadirkan layanan mobile payment yang lebih baik bagi masyarakat Indonesia (www.cnnindonesia.com).

Dalam fitur LinkAja tidak ada perbedaan yang dulu T-Cash menjadi LinkAja. Layanan maupun fitur yang tersedia pada T-Cash masih dapat diakses di aplikasi LinkAja dan pengguna T-Cash sebelumnya tidak perlu registrasi ulang saat menggunakan LinkAja. Penyediaan layanan maupun sistem dari aplikasi m-payment LinkAja masih tetap berada dalam naungan PT. Telekomunikasi Indonesia (Telkomsel).

Sebagai informasi, data pengguna dompet digital Gojek merupakan jumlah pengguna aktif bulanan Go-Pay dan layanan lainnya dari aplikasi Gojek. Peringkat selanjutnya diraih oleh Ovo yang berhasil unggul selama empat kuartal berturut-turut. Sebelumnya, Ovo sempat bersaing dengan LinkAja memperebutkan posisi kedua. Dan pada tahun 2019 Gojek masih menduduki posisi pertama, Ovo posisi kedua, Dana yang kurang popular tapi pada tahun 2018-2019 meningkat dan menduduki posisi ketiga, serta LinkAja mendapatkan posisi keempat.

Alvara Research Center melakukan survei mengenai layanan pembayaran digital pada tanggal 3 - 20 April 2019. Survei tersebut melibatkan 1.204 responden yang berasal dari beberapa daerah di Indonesia yakni Jabodetabek, Padang, Bali, Manado, dan Yogyakarta. Hasil survey menerangkan bahwa LinkAja masih menempati posisi terakhir dibandingkan dengan aplikasi m-payment lainnya berdasarkan indikator total awareness, top of mind, dan future intention. Hal ini tentu mengindikasikan bahwa LinkAja kurang populer dan diminati oleh masyarakat. Dengan adanya fenomena penurunan minat penggunaan LinkAja yang sudah dipaparkan, kurangnya kepopuleran LinkAja dibanding aplikasi pembayaran digital lainnya, serta dengan adanya perubahan nama produk T-Cash menjadi LinkAja yang mengakibatkan masyarakat kurang mengetahui aplikasi tersebut.

Kepercayaan yang dirasakan bahwa penggunaan informasi sensitive dalam layanan keuangan inovatif ini biasanya menimbulkan beberapa kekhawatiran terkait keamanan dan privasi pembayaran seluler. Pengaruh signifikan dari kepercayaan pembayaran seluler awal pada niat perilaku ditemukan oleh ( $\mathrm{Lu}$ et al.,2011). Arvidsson (2014) juga menegaskan pengaruh signifikan kepercayaan terhadap sikap konsumen dalam mengadopsi layanan pembayaran seluler. Kumar dkk. (2018) melaporkan bahwa kepercayaan dengan penyedia layanan $m$-wallet secara positif mempengaruhi niat keberlanjutan m.payment. Chaouali dan El Hedhli (2019) melaporkan kepercayaan sebagai penentu paling signifikan dari adopsi mobile banking. Pengaruh lain yang menjadi pertimbangan seseorang untuk menggunakan mobile payment adalah kegunaan yang dirasakan adalah salah satu konstruksi TAM (Technology Acceptance Model) asli yang paling penting dan telah dipelajari secara komprehensif sebagai variabel sentral dalam adopsi teknologi baru, termasuk mpayment (Dalhberg et al., 2015) dan m-banking (Baptista dan Oliveira, 2016; Shaikh dan Karjaluoto, 2015). Sebagai platform pembayaran berbasis digital yang terkoneksi 
dengan internet, LinkAja tentunya harus dapat menjamin keamanan bagi penggunanya. Keamanan yang dirasakan didefinisikan sebagai sejauh mana pengguna percaya bahwa menggunakan saluran pembayaran online tertentu akan aman dan ini membantu dalam membangun kepercayaan, mengembangkan sikap dan niat positif untuk mengadopsi inovasi teknologi. Dalam studi e-commerce dan belanja online, keamanan merupakan penentu kepercayaan yang signifikan (Flavian dan Guinali'u, 2006; Roca et al., 2009; Kim et al., 2011). Pada penelitian Carlos Flavian dan Miguel Guinaliu (2020) menunjukkan bahwa persepsi kemudahan penggunaan (PEOU) berpengaruh secara signifikan terhadap sikap maupun niat pengguna mobile payment, sedangkan berdasarkan hasil pengujian oleh Deepak Chawla and Himanshu Joshi (2019) menunjukkan bahwa persepsi kemudahan penggunaan tidak berpengaruh secara signifikan terhadap niat pengguna mobile payment. Sedangkan hasil pengujian oleh Deepak Chawla and Himanshu Joshi (2019) menunjukkan bahwa keamanan yang dirasakan tidak berpengaruh secara signifikan terhadap niat menggunakan mobile payment sedangkan berdasarkan hasil pengujian oleh Choi-Meng Leong, Kim-Lim Tan, Chin-Hong, Puah, Shyh-Ming Chong (2020), menunjukkan bahwa keamanan yang dirasakan berpengaruh signifikan terhadap niat menggunakan mobile payment.

\section{METODE PENELITIAN}

Populasi mengacu pada seluruh kelompok orang, kejadian, atau hal-hal yang menarik yang peneliti ingin selidiki (Sekaran dan Bougie, 2016). Populasi yang digunakan dalam penelitian ini adalah seluruh mahasiswa di Yogyakarta yang menggunakan LinkAja. Sampel dalam penelitian ini adalah mahasiswa yang menggunakan aplikasi mobile payment LinkAja yang berada di Yogyakarta sebagai alat pembayarannya. Pengambilan sampel dilakukan dengan purposive sampling. Purposive sampling yaitu teknik pengambilan sampel dengan pertimbangan tertentu, ketika memilih orang sebagai sampel yang benar-benar mengetahui atau memiliki kompetensi dengan penelitian ini (Sekaran dan Bougie, 2016). Pengambilan data dilakukan pada bulan Januari. Sampel sebanyak 225 responden. Teknik analisis data menggunakan Partial Least Square(PLS).

\section{ANALISIS DAN PEMBAHASAN Analisis Deskriptif}

Tabel 3.1 Jenis Kelamin

\begin{tabular}{|c|c|c|}
\hline Jenis Kelamin & Persentase & Jumlah \\
\hline Perempuan & $67,11 \%$ & 151 \\
\hline Laki-laki & $32,89 \%$ & 74 \\
\hline Total & $\mathbf{1 0 0} \%$ & $\mathbf{2 2 5}$ \\
\hline
\end{tabular}

Sumber: data diolah,2021

Tabel 3.2 Umur

\begin{tabular}{|c|c|c|}
\hline Umur & Persentase & Jumlah \\
\hline $18-25$ tahun & $97,78 \%$ & 220 \\
\hline $26-35$ tahun & $2,22 \%$ & 5 \\
\hline $36-45$ tahun & - & - \\
\hline$>45$ tahun & - & - \\
\hline Total & $\mathbf{1 0 0} \%$ & $\mathbf{2 2 5}$ \\
\hline
\end{tabular}

Sumber: data diolah, 2021
The intention to use

LinkAja mobile payments 
The intention to use LinkAja mobile payments

\section{4

Tabel 3.3 Jenjang Pendidikan
\begin{tabular}{|l|c|c|}
\hline Jenjang Pendidikan & Persentase & Jumlah \\
\hline Diploma & $9,78 \%$ & 22 \\
\hline Sarjana (S1) & $89,78 \%$ & 202 \\
\hline Magister (S2) & $0,44 \%$ & 1 \\
\hline Doktor (S3) $\quad-$ & - \\
\hline \multicolumn{1}{|c|}{ Total } & $\mathbf{1 0 0} \%$ & $\mathbf{2 2 5}$ \\
\hline
\end{tabular}

Sumber: data diolah, 2021

Tabel 3.4 Uang saku/Pendapatan Perbulan

\begin{tabular}{|l|c|c|}
\hline $\begin{array}{l}\text { Uang saku/Pendapatan } \\
\text { Perbulan }\end{array}$ & Persentase & Jumlah \\
\hline$\leq R p 1$ juta & $63,11 \%$ & 142 \\
\hline Rp 1 juta - Rp 5 juta & $35,11 \%$ & 79 \\
\hline Rp 5 juta - Rp 10 juta & $1,33 \%$ & 3 \\
\hline$>10$ juta & $0,44 \%$ & 1 \\
\hline Total & $\mathbf{1 0 0 \%}$ & $\mathbf{2 2 5}$ \\
\hline
\end{tabular}

Sumber: data diolah, 2021

Tabel 3.5 Perguruan Tinggi di Yogyakarta

\begin{tabular}{|c|c|}
\hline Perguruan Tinggi di Yogyakarta & Jumlah \\
\hline UPNVYK & 128 \\
\hline UGM & 22 \\
\hline UNY & 17 \\
\hline UMY & 17 \\
\hline AMIKOM & 7 \\
\hline UAJ YOGYAKARTA & 4 \\
\hline UIN YOGYAKARTA & 3 \\
\hline PGRI YOGYAKARYA & 3 \\
\hline UII & 3 \\
\hline UAD YOGYAKARTA & 3 \\
\hline POLTEKKES KEMENKES YOGYAKARTA & 2 \\
\hline UMBY & 2 \\
\hline UNIV. ALMA ATA YK & 2 \\
\hline UTY & 2 \\
\hline AA YKPN & 2 \\
\hline STTKD & 2 \\
\hline UST & 1 \\
\hline STIE SBI YOGYAKARTA & 1 \\
\hline STIKES PANTI RAPIH YK & 1 \\
\hline UNISA & 1 \\
\hline STIPRAM YK & 1 \\
\hline POLITEKNIK LPP YK & 1 \\
\hline Total & $\mathbf{2 2 5}$ \\
\hline
\end{tabular}

Sumber: data diolah, 2021

\section{Analisis Deskriptif Variabel}

\section{a. Kepercayaan}

Dari 225 responden yang diambil sebagai sampel, diketahui rata-rata responden menilai kepercayaan tinggi (Mean 4,19). Hal ini dapat disimpulkan bahwa responden percaya penggunaan mobile payment akan meningkatkan kinerja pekerjaannya. 
b. Kegunaan

Dari 225 responden yang diambil sebagai sampel, diketahui rata-rata responden menilai kegunaan tinggi (Mean 4,15). Hal ini menyatakan bahwa responden dalam menggunakan mobile payment LinkAja berguna untuk mahasiswa di Yogyakarta.

\section{c. Keamanan}

Dari 225 responden yang diambil sebagai sampel, diketahui rata-rata responden menilai keamanan tinggi (Mean 4,19). Dapat disimpulkan responden dalam menggunakan mobile payment LinkAJa mempunyai keamanan yang tinggi untuk memecahkan masalah dari para pemakai akun palsu.

\section{d. Kemudahan}

Dari 225 responden yang diambil sebagai sampel, diketahui rata-rata responden menilai kemudahan sangat tinggi (Mean 4,15). Hal ini menyatakan bahwa responden dalam menggunakan mobile payment LinkAja menunjukkan kemudahan para mahasiswa di Yogyakarta.

\section{e. Minat Menggunakan}

Dari 225 responden yang diambil sebagai sampel, diketahui rata-rata responden menilai Minat Menggunakan tinggi (Mean 4,15). Maka dapat ditarik kesimpulan bahwa responden akan tetap menggunakan dan terus menggunakan mobile payment LinkAja sebagai metode pembayaran.

\section{A. Analisis Kuantitatif \\ 1. Outer Model (Model Pengukuran) \\ a. Convergent Validity}

Yaitu nilai loading faktor pada variabel laten dengan indikatornya. Nilai loading factor $>0,7$. Dalam penelitian ini akan digunakan batas loading factor sebesar 0,7. Berikut adalah pelaporan tabel hasil uji outer loading (Convergent Validity) 225 responden. Berdasarkan hasil Outer loading 225 Responden diketahui bahwa masing masing indicator variable penelitian memiliki outer loading $>0,7$. Menurut Chin yang dikutip oleh Imam Ghozali, mengatakan bahwa nilai outer loading antara $>0,7$ sudah dianggap sangat baik untuk memenuhi syarat convergent validity.

\section{b. Discriminant Validity}

Yaitu nilai korelasi cross loading dengan variabel latennya harus lebih besar $>0,70$. Berikut adalah pelaporan tabel hasil uji Cross loadings (Discriminant Validity). Berdasarkan Uji Validitas menunjukka semua indikator yang melalui uji Cross loadings (Discriminant Validity) adalah valid karena sudah melebihi 0,7 dan lebih besar dibandingkan dengan nilai loading dengan variabel yang lain.

\section{c. Composite Reliability}

Composite reliability merupakan bagian yang digunakan untuk menguji nilai reliabilitas indikator-indikator pada suatu variabel. Suatu variable dapat dinyatakan memenuhi composite reliability apabila memiliki nilai composite reliability $>0,6$ (Ghozali, 2014). Berdasarkan uji reliabilitas semua variabel laten mempunyai nilai composite reliability $>0,6$. Hasil ini menunjukkan bahwa masing-masing variabel telah memenuhi composite reliability sehingga dapat disimpulkan bahwa keseluruhan variabel memiliki tingkat reliabilitas yang tinggi.

\section{d. Average Variance Extracted (AVE)}

Hussein (2015) mengatakan nilai $A V E$ yang diharapkan $>0,5$, untuk bisa dikatakan valid. Berikut adalah pelaporan tabel hasil uji Average Variance Extracted (AVE): Berdasarkan hasil Average Variance Extracted (AVE) dari 225 Responden semua variabel laten mempunyai nilai $A V E \geq 0,5$. Dengan demikian dapat dinyatakan bahwa setiap variabel telah memiliki validitas yang baik.

\section{e. Cronbach's Alpha}

Uji reliabilitas dengan composite reability di atas dapat diperkuat dengan menggunakan nilai cronbach alpha. Suatu variabel dapat dinyatakan reliabel atau memenuhi cronbach alpha apabila memiliki nilai cronbach alpha > 0,7 (Ghozali, 2014). Berdasarkan hasil uji reliabilitas Cronbach's Alpha 225 Responden, dapat diketahui
The intention to use

LinkAja mobile payments 
The intention to use LinkAja mobile payments

bahwa nilai cronbach alpha dari masing-masing variabel penelitian $>0,7$. Dengan demikian, hasil ini dapat menunjukkan bahwa masing-masing variabel penelitian telah memenuhi persyaratan nilai cronbach alpha dan memiliki tingkat reliabekl tinggi.

2. Inner Model (Model Struktural)

Tabel 3.16 Hasil Uji Inner Model Struktural

\begin{tabular}{|c|c|}
\hline Pengujian & Hasil Uji \\
\hline $\begin{array}{l}\text { Koefisien Determinasi (Rsquare) } \\
\text { Kemudahan (R1) } \\
\text { Minat Menggunakan (R2) }\end{array}$ & $\begin{array}{l}0,822 \\
0,864\end{array}$ \\
\hline $\begin{array}{l}\mathrm{Q}^{2} \text { predictive relevance } \\
\mathrm{Q}^{2}=1-\left(1-\left(\mathrm{R}^{2}\right)\left(1-\mathrm{R}^{2}\right)\right) \\
\quad=1-\left(1-\left(0,822^{2}\right)\left(1-0,864^{2}\right)\right) \\
\quad=1-(1-0,675684)(1-0,746496) \\
\quad=1-(0,324316)(0,253504) \\
\quad=0,91778459674\end{array}$ & $91,78 \%$ \\
\hline $\begin{array}{l}\text { Goodness of Fit (GoF) } \\
\begin{aligned} \text { GoF } & =\sqrt{\overline{A V E} \times \overline{R^{2}}} \\
& =\sqrt{0,695 \times 0,864^{2}} \\
& =\sqrt{0,766 \times 0,746496} \\
& =0,571815936\end{aligned}\end{array}$ & 0,5718 \\
\hline
\end{tabular}

Sumber: data diolah, 2021

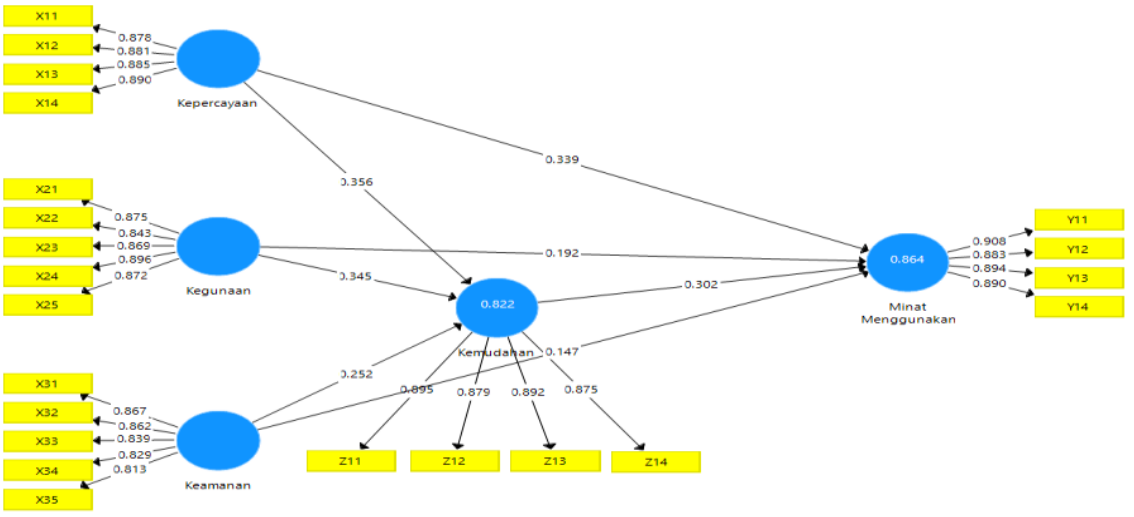

Gambar 3.1 Hasil Algorithm 225 Responden

Penafsiran :

a. Koefisien determinasi $\left(\mathbf{R}^{2}\right)$

$\mathrm{R}^{2}$ Menunjukkan bahwa Kemudahan dipengaruhi oleh Kepercayaan, Kegunaan dan Keamanan sebesar 82,2\% sisanya sebesar 17,8\% dipengaruhi oleh faktor lain yang tidak terdapat dalam model. Sedangkan Minat Menggunakan dipengaruhi oleh Kepercayaan, Kegunaan, Keamanan dan Kemudahan sebesar 86,4\%, sisanya $13,6 \%$ dipengaruhi oleh faktor lain yang tidak tedapat dalam model.

b. $\mathbf{Q}-$ square predictive relevance $\left(\mathbf{Q}^{2}\right)$

Minat Menggunakan dipengaruhi oleh Kepercayaan, Kegunaan, Keamanan dan Kemudahan sebesar $91,78 \%$ artinya bahwa nilai-nilai yang diobservasi sudah direkonstruksi dengan baik dengan mempunyai relevansi prediktif.

c. Goodness of Fit (GoF)

Nilai Goodness of Fit (GoF) dalam penelitian ini adalah 0,5718 yang berarti besar.

\section{A. Hasil Pengujian Hipotesis}

Pengujian hipotesis dilakukan dengan mengamati nilai t hitung dan nilai signifikansi.

Nilai thitung yang direkomendasikan adalah $\geq 1.96$ dan nilai signifikansi atau $p$-value $\leq$ 0.05. Hasil uji hipotesis dapat dilihat dalam tabel 3.17. 
Tabel 3.17 Hasil Uji Pengaruh Langsung

\begin{tabular}{|l|c|c|c|c|c|}
\hline & Original Sample (O) & $\begin{array}{c}\text { Sample } \\
\text { Mean } \\
(\mathbf{M})\end{array}$ & $\begin{array}{c}\text { Standard } \\
\text { Deviation } \\
\text { (STDEV) }\end{array}$ & $\begin{array}{c}\text { T Statistics } \\
(\mid \text { O/STDEV |) }\end{array}$ & $\begin{array}{c}\mathbf{P} \\
\text { Values }\end{array}$ \\
\hline $\mathbf{X 1 ~} \rightarrow \mathbf{Y}$ & 0,339 & 0,342 & 0,078 & 4,325 & $\mathbf{0 , 0 0 0}$ \\
\hline $\mathbf{X} \mathbf{2} \rightarrow \mathbf{Y}$ & 0,192 & 0,187 & 0,066 & 2,913 & $\mathbf{0 , 0 0 4}$ \\
\hline $\mathbf{X 3 \rightarrow \mathbf { Y }}$ & 0,147 & 0,161 & 0,068 & 2,169 & $\mathbf{0 , 0 3 1}$ \\
\hline $\mathbf{Z} \rightarrow \mathbf{Y}$ & 0,302 & 0,290 & 0,104 & 2,906 & $\mathbf{0 , 0 0 4}$ \\
\hline
\end{tabular}

Sumber: data diolah, 2021

Hipotesis 1: Kepercayaan berpengaruh positif terhadap Minat Menggunakan Mobile Payment LinkAja.

Berdasarkan tabel analisis jalur, Kepercayaan berpengaruh positif dan signifikan terhadap Minat Menggunakan Mobile Payment LinkAja, karena T-statistic 4,325 > 1,96 dan P-value sebesar $0,000<0.05$. Dengan demikian Kepercayaan berpengaruh positif dan signifikan terhadap Minat Menggunakan Mobile Payment LinkAja. Hal ini menyatakan H0 ditolak dan Ha diterima.

Hipotesis 2: Kegunaan berpengaruh positif terhadap Minat Menggunakan Mobile Payment LinkAja.

Berdasarkan tabel analisis jalur, Kegunaan berpengaruh positif dan signifikan terhadap Minat Menggunakan Mobile Payment LinkAja karena T-statistic 2,913 > 1,96 dan P-value sebesar $=0,04<0.05$. Dengan demikian Kegunaan berpengaruh positif dan signifikan terhadap Minat Menggunakan Mobile Payment LinkAja. Hal ini menyatakan H0 ditolak dan Ha diterima.

Hipotesis 3 : Keamanan berpengaruh positif dan signifikan terhadap Minat Menggunakan Mobile Payment LinkAja.

Berdasarkan tabel analisis jalur, keamanan berpengaruh positif dan signifikan terhadap Minat Menggunakan Mobile Payment LinkAja karena T-statistic 2,169 > 1,96 dan P-value sebesar $=0,031<0.05$. Dengan demikian Keamanan berpengaruh positif terhadap Minat Menggunakan Mobile Payment LinkAja. Hal ini menyatakan H0 ditolak dan Ha diterima. Hipotesis 4: Kemudahan berpengaruh positif terhadap Minat Menggunakan Mobile Payment LinkAja.

Berdasarkan tabel analisis jalur, kemudahan berpengaruh positif dan signifikan terhadap minat menggunakan mobile payment LinkAja karena T-statistic 2,169>1,96 dan P-value sebesar $=0,031<0.05$. Dengan demikian keamanan berpengaruh positif terhadap minat menggunakan mobile payment LinkAja. Hal ini menyatakan $\mathrm{H} 0$ ditolak dan Ha diterima.

\section{Tabel 3.18 Hasil Uji Pengaruh Tidak Langsung}

\begin{tabular}{|l|c|c|c|}
\hline & $\begin{array}{c}\text { Specific } \\
\text { Indirect } \\
\text { Effects }\end{array}$ & $\begin{array}{c}\text { T Statistics } \\
(\mid \text { O/STDEV|) }\end{array}$ & P Values \\
\hline $\mathrm{X} 1 \rightarrow \mathbf{Z} \rightarrow \mathbf{Y}$ & 0,059 & 2,751 & 0,020 \\
\hline $\mathrm{X} 2 \rightarrow \mathrm{Z} \rightarrow \mathrm{Y}$ & 0,054 & 2,289 & 0,023 \\
\hline $\mathrm{X} 3 \rightarrow \mathrm{Z} \rightarrow \mathbf{Y}$ & 0,056 & 2,339 & 0,006 \\
\hline
\end{tabular}

Hipotesis5:Kepercayaan berpengaruh positif dan signifikan terhadap minat menggunakan mobile payment LinkAja melalui kemudahan.

Berdasarkan tabel analisis jalur, kepercayaan berpengaruh positif dan signifikan terhadap minat menggunakan mobile payment LinkAja melalui kemudahan, karena T-statistic 2,751 $>1,96$ dan $P$-value sebesar $=0,006<0.05$. Dengan demikian kepercayaan berpengaruh positif dan signifikan terhadap minat menggunakan mobile payment LinkAja melalui kemudahan, hal ini menyatakan $\mathrm{H} 0$ ditolak dan Ha diterima.
The intention to use LinkAja mobile payments 
The intention to use

LinkAja mobile

payments

338
Hipotesis 6: Kegunaan berpengaruh positif dan signifikan terhadap minat menggunakan mobile payment LinkAja melalui kemudahan.

Berdasarkan tabel analisis jalur, kegunaan berpengaruh positif dan signifikan terhadap minat menggunakan mobile payment LinkAja melalui kemudahan, karena T-statistic $2,289>1,96$ dan $\mathrm{P}$-value sebesar $=0,023<0.05$. Dengan demikian kegunaan berpengaruh positif dan Signifikan terhadap minat menggunakan mobile payment LinkAja melalui kemudahan. Hal ini menyatakan $\mathrm{H} 0$ ditolak dan Ha diterima.

Hipotesis 7: Keamanan berpengaruh positif dan signifikan terhadap minat menggunakan mobile payment LinkAja melalui kemudahan.

Berdasarkan tabel analisis jalur, keamanan berpengaruh positif dan signifikan terhadap minat menggunakan mobile payment LinkAja melalui kemudahan karena T-statistic 2,339> 1,96 dan $P$-value sebesar $=0,020<0.05$. Dengan demikian keamanan berpengaruh positif dan signifikan terhadap minat menggunakan mobile payment LinkAja melalui kemudahan. $\mathrm{Hal}$ ini menyatakan $\mathrm{H} 0$ ditolak dan $\mathrm{Ha}$ diterima.

\section{B. Pembahasan}

\section{Pengaruh Kepercayaan terhadap Minat Menggunakan Mobile Payment LinkAja}

Hasil penelitian ini menunjukkan bahwa kepercayaan mempunyai pengaruh terhadap minat menggunakan, mendukung Saif-Ur-Rehman, Ch. Muhammad Salman Abid, Zeshan Ahmer (2020) yang menyatakan bahwa kepercayaan yang dapat memiliki pengaruh yang signifikan pada tingkat kepercayaan, Karena kepercayaan ditemukan Temuan ini juga konsiten bahwa pengaruh signifikan dari kepercayaan pembayaran seluler awal pada niat perilaku ditemukan oleh Lu et al. (2011). Kepercayaan awal pelanggan pada layanan pembayaran seluler secara positif mempengaruhi persepsi mereka tentang keuntungan relatif, meningkatkan niat mereka untuk menggunakan layanan pembayaran seluler. Kepercayaan yang baik dan positif akan menimbulkan Minat Menggunakan yang tinggi pada pengguna mobile payment. Persepsi Kepercayaan seperti memberikan jasa sesuai yang mereka janjikan, selalu memperhatikan minat pengguna dan kompenten, efektif dalam menyediakan layanan keuangan.

\section{Pengaruh Kegunaan terhadap Minat Menggunakan Mobile Payment LinkAja}

Hasil penelitian ini menunjukkan bahwa kegunaan mempunyai pengaruh terhadap minat menggunakan mobile payment LinkAja, ini mendukung Carlos Flavian dan Miguel Guinaliu, 2020 yang menyatakan bahwa dipersepsi kegunaan ditemukan memiliki pengaruh positif dan signifikan terhadap niat untuk menggunakan. Temuan ini juga konsisten dengan penelitian Muhammad Haidhar Ibrahim, Siti Rahayu Hussin, Siti Haslina Hussin, (2019) memiliki hubungan positif yang signifikan dengan niat untuk menggunakan pembayaran seluler. Hal tersebut terbentuk karena adanya kegunaan yang positif dari pengguna mobile payment LinkAja. Kesimpulannya bahwa minat menggunakan akan semakin tinggi apabila Pengguna merasakan kegunaan yang baik. Dengan kata lain, kegunaan yang baik dan positif akan menimbulkan minat menggunakan yang tinggi pada pengguna mobile payment LinkAja.

\section{Pengaruh Keamanan terhadap Minat Menggunakan Mobile Payment LinkAja}

Hasil penelitian ini menunjukkan bahwa keamanan mempunyai pengaruh terhadap minat menggunakan mobile payment LinkAja, ini mendukung oleh Choi-Meng Leong, Kim-Lim Tan, Chin-Hong, Puah, Shyh-Ming Chong (2020), menunjukkan bahwa keamanan yang dirasakan berpengaruh signifikan terhadap niat menggunakan mobile payment. Hasil penelitian ini juga konsisten dengan penelitian Haidhar Ibrahim, Siti Rahayu Hussin, Siti Haslina Hussin, (2019) mengatakan bahwa keamanan berpengaruh signifikan dalam menentukan niat untuk menggunakan pembayaran seluler.

Hal tersebut terbentuk karena adanya keamanan yang positif dari pengguna mobile payment LinkAja. Kesimpulannya bahwa minat menggunakan akan semakin tinggi apabila pengguna merasakan keamanan yang baik. Dengan kata lain, keamanan yang baik dan positif akan menimbulkan minat menggunakan yang tinggi pada pengguna mobile payment LinkAja. 
Pengaruh Kemudahan terhadap Minat Menggunakan Mobile Payment LinkAja

Hasil penelitian ini menunjukkan bahwa kemudahan mempunyai pengaruh terhadap minat menggunakan, ini mendukung Carlos Flavian dan Miguel Guinaliu (2020) menunjukkan bahwa persepsi kemudahan penggunaan (PEOU) berpengaruh secara signifikan terhadap sikap maupun niat pengguna mobile payment. Jadi dilihat dari teori yang dikemukakan dengan adanya m-paymet LinkAja bahwa kenyamanan dan tingkat kesulitan menggunakan kartu kredit, dijelaskan dengan adanya m-payment LinkAja yang diterima dikalangan mahasiswa di Yogyakarta bahwa memiliki kemudahan penggunaan yang lebih tinggi daripada kartu kredit.

Hal tersebut terbentuk karena adanya Kemudahan yang positif dari pengguna mobile payment LinkAja. Kesimpulannya bahwa Minat Menggunakan akan semakin tinggi apabila Pengguna merasakan Kemudahan yang baik. Dengan kata lain, kemudahan yang baik dan positif akan menimbulkan minat menggunakan yang tinggi pada pengguna mobile payment LinkAja sangat tinggi atau dengan kata lain Kemudahan sangat baik.

Pengaruh Kepercayaan terhadap Minat Menggunakan Mobile Payment LinkAja melalui Kemudahan

Hasil penelitian ini menunjukkan bahwa kepercayaan mempunyai pengaruh terhadap minat menggunakan mobile payment Linkaja melalui kemudahan, ini mendukung penelitian (Pavlou, 2003) melaporkan pengaruh kepercayaan terhadap persepsi kemudahan penggunaan dan paling signifikan dari niat untuk menggunakan $m$ payment. Dalam konteks m-payment, kepercayaan akan mengurangi kebutuhan konsumen untuk memantau tindakan pengecer Web dan memeriksa setiap detail, membuat transaksi online lebih mudah. Maka dari itu, jika membangun kepercayaan disandingkan dengan kemudahan menjadikan para mahasiwa di Yogyakarta selalu dapat menggunakan tanpa adanya kesulitan. Kesimpulannya bahwa kepercayaan melalui kemudahan dalam minat menggunakan, bila minat menggunakan semakin tinggi apabila pengguna merasakan kepercayaan melalui kemudahan yang baik. Dengan kata lain, kepercayaan melalui kemudahan yang baik dan positif akan menimbulkan minat menggunakan yang tinggi pada pengguna mobile payment LinkAja.

Pengaruh Kegunaan terhadap Minat Menggunakan Mobile Payment Linkaja melalui Kemudahan

Hasil penelitian ini menunjukkan bahwa kegunaan mempunyai pengaruh terhadap minat menggunakan Mobile Payment LinkAja melalui kemudahan, ini sejalan dengan penelitian Choi-Meng Leong, Kim-Lim Tan, Chin-Hong, Puah, Shyh-Ming Chong (2020) menunjukkan bahwa persepsi kegunaan berpengaruh secara signifikan terhadap kemudahan dalam menggunakan mobile payment LinkAja. kegunaan dan kemudahan ditemukan terkait langsung dengan intention to use, layanan pembayaran seluler yang ditawarkan oleh operator jaringan seluler. Oleh karena itu, kegunaan mewakili sejauh mana pengguna memiliki kepercayaan dalam menggunakan system m-payment yang akan meningkatkan hasil sementara. Jika kegunaan dan kemudahan dilakukan secara bersama maka akan mempermudah penggunaan m-payment LinkAja bagi mahasiswa di Yogyakarta.

Dalam penelitian ini yang dilakukan kepada 225 responden, diperoleh hasil rata-rata responden mempunyai skor jawaban untuk kegunaan yaitu 4,05 yang menunjukkan bahwa pengguna Mobile Payment LinkAja dikalangan Mahasiswa Yogyakarta telah berhasil menciptakan kegunaan karena kegunaan berada pada kategori tinggi atau dengan kata lain kegunaan baik. Kesimpulannya bahwa minat menggunakan akan semakin tinggi apabila pengguna merasakan kegunaan apabila kemudahan dioperasikan dengan baik. Dengan kata lain, persepsi kegunaan melalui kemudahan yang baik dan positif akan menimbulkan minat menggunakan yang tinggi pada pengguna mobile payment LinkAja

Pengaruh Keamanan terhadap Minat Menggunakan mobile payment LinkAja melalui Kemudahan

Hasil penelitian ini menunjukkan bahwa keamanan mempunyai pengaruh terhadap minat menggunakan Mobile Payment LinkAja melalui kemudahan, yang ditunjukkan oleh
The intention to use

LinkAja mobile

payments 
The intention to use LinkAja mobile payments nilai $T$-statistic 2,339> 1,96 dan $P$-value sebesar $=0,020<0.05$. Hasil penelitian ini mendukung Choi-Meng Leong, Kim-Lim Tan, Chin-Hong, Puah, Shyh-Ming Chong (2020) menunjukkan bahwa ada hubungan langsung dari perceived security ke perceived ease of use. Temuan ini sejalan dengan Hartono et al. (2014) menemukan bahwa pengguna merasa lebih nyaman dalam menggunakan sistem jika perceived security meningkat. Oleh karena itu, pengguna membutuhkan rasa aman yang lebih besar saat melakukan transaksi keuangan, yang menurut Laforet dan Li (2005) merupakan faktor terpenting yang memotivasi konsumen dalam mengadopsi mpayment. Dengan kata lain, jika pengguna menganggap m-payment menguntungkan bagi mereka dan dikombinasikan dengan persepsi tentang peningkatan fitur keamanan, maka wajar untuk mengharapkan sikap terhadap penggunaan m-payment akan positif, Sehingga persepsi keamanan melalui kemudahan yang baik dan positif akan menimbulkan minat menggunakan yang tinggi pada pengguna mobile paymen LinkAja.

\section{SIMPULAN DAN SARAN}

\section{A. KESIMPULAN}

Kesimpulan dari penelitian ini adalah:

Kepercayaan berpengaruh positif dan signifikan terhadap Minat Menggunakan mobile payment LinkAja pada Mahasiswa di Yogyakarta. Kegunaan berpengaruh positif dan signifikan terhadap Minat Menggunakan mobile payment LinkAja pada Mahasiswa di Yogyakarta. Keamanan berpengaruh positif dan signifikan terhadap Minat Menggunakan mobile payment LinkAja pada Mahasiswa di Yogyakarta. Kemudahan berpengaruh positif dan signifikan terhadap Minat Menggunakan mobile payment LinkAja pada Mahasiswa di Yogyakarta. Kepercayaan berpengaruh positif dan signifikan terhadap minat menggunakan mobile payment LinkAja melalui kemudahan pada mahasiswa di Yogyakarta. Kegunaan berpengaruh positif dan signifikan terhadap minat menggunakan mobile payment LinkAja melalui kemudahan pada mahasiswa di Yogyakarta. Keamanan berpengaruh positif dan signifikan terhadap minat menggunakan mobile payment LinkAja melalui kemudahan pada mahasiswa di Yogyakarta.

\section{DAFTAR PUSTAKA}

[1] Au, Y.A. and Kauffman, R.J. (2008), "The economics of mobile payments: understanding stakeholder issues for an emerging financial technology application", Electronic Commerce Research and Applications, Vol. 7 No. 2, pp. 141-164.

[2] Arvidsson, N. (2014), "Consumer attitudes on mobile payment services - results from a proof of concept test", International Journal of Bank Marketing, Vol. 32 No. 2, pp. 150-170.

[3] Chaouali, W. and El Hedhli, K. (2019), "Toward a contagion-based model of mobile banking adoption", International Journal of Bank Marketing, Vol. 37 No. 1, pp. 69-96.

[4] Chawla, Deepak And Himanshu Joshi.(2019), "The Moderating Role Of Gender And Age InThe Adoption Of Mobile Wallet",International Journal Of Deepak Department Of Quantitative Techniques And Operations Management, International Management Institute,New Delhi, India. ISSN 1463-6689.

[5] Dalhberg, T., Guo, J. and Ondrus, J. (2015), "A critical review of mobile payment research", Electronic Commerce Research and Applications, Vol. 14 No. 5, pp. 265-284.

[6] Davis, F. D., Bagozzi, R. P., \& Warshaw, P. R. 1991, "Extrinsic and intrinsic motivation to use computers in the workplace". Journal of Applied Social Psychology, Vol.22, no.14, p. 1111.

[7] Davis, F. D. (1986). A technology acceptance model for empirically testing new enduser information systems: Theory and results. Management, Ph.D.(April), 291. https://doi.org/oclc/56932490

[8] Davis, F.D., 1989. Perceived usefulness, perceived ease of use, and user acceptance. MIS Quarterly, 13(3), pp.319-340. 
[9] Davis, F. D., Bagozzi, R. P., \& Warshaw, P. R. 1992, "Extrinsic and intrinsic motivation to use computers in the workplace". Journal of Applied Social Psychology, Vol.22, no.14, p. 1111.

[10] Emarketer (2017a), "Emarketer Releases Latest Estimates For US Proximity Mobile Payments",AvailableAt:Www.Emarketer.Com/Article/EmarketerReleases Latest-Estimates-US-Proximity-Mobilepayments/1016417 (AccessedDecember 12, 2018).

[11] Flavian, Carlos., And Miguel Guinaliu, Yuntao Lu. (2020), "Mobile Payments Adoption Introducing Mindfulness To Better Understand Consumer Behavior", International Journal Of BankMarketing.

[12] Ghozali, Imam. 2015. Structural Equation Modeling, Metode Alternatif dengan Partial Least Square (PLS). Edisi 5. Semarang : Badan Penerbit Universitas Diponegoro.

[13] Ghozali, I. (2018). Aplikasi Multivariate dengan Program SPSS 25. Semarang: Badan Penerbit Universitas Diponegoro.

[14] Ibrahim, Muhammad Haidhar., Siti Rahayu Hussin, Siti Haslina Hussin. (2019), "Factors Influencing Malaysian Consumers' Intention To Use Quick Response(QR) Mobile Payment", Jurnal Pengurusan 57, Galley Proof ISSN 0127-2713 Scopus, Cabell, ASEAN Citation Index (ACI) And Mycite Indexes.

[15] Kim, C., Mirusmonov, M. And Lee, I. (2010), "An Empirical ExaminationOf Factors Influencing TheIntention To Use Mobile Payment", Computers In Human Behavior, Vol. 26 No. 3, Pp. 310-322.

[16] Kumar, A., Adlakaha, A. and Mukherjee, K. (2018), "The effect of perceived security and grievance redressal on continuance intention to use M-wallets in a developing country", International Journal of Bank Marketing, Vol. 36 No. 7, pp. 1170-1189.

[17] Liu, Y. (2015), "Consumer protection in mobile payments in China: a critical analysis of Alipay's service agreement", Computer law and security review, Vol. 31 No. 5, pp. 679-688.

[18] Lu, Y. et al., 2011. Dynamics between the trust transfer process and intention to use mobile payment services: a cross-environment perspective", Information \& Management, Vol. 48 No. 8, pp. 393-403, doi:

[19] Lwonga, E.T. and Lwonga, N.B. (2017), "User acceptance of mobile payment: the effects of user-centricsecurity, system characteristics and gender", The Electronic Journal of Information Systems inDeveloping Countries, Vol. 81 No. 3, pp. 1-24.

[20] M, Anindya Ratna., 2019.

[21] Https://Openlibrary.Telkomuniversity.Ac.Id/Pustaka/Files/157560/Bab1/Anali siFaktor-Faktor-Yang-Mempengaruhi-Niat-Keberlanjutan-Penggunaan AplikasiLinkaja.Pdf.

[22] Oliveira, T., Thomas, M., Baptista, G. \& Campos, F. 2016. Mobile payment: Understanding the determinants of customer adoption and intention to recommend the technology. Computers in Human Behavior 61: 404414.

[23] Ou, C.M. and Ou, C.R. (2009), "Adaptation of proxy certificates to nonrepudiation protocol of agentbased mobile payment systems", Applied Intelligence, Vol. 30 No. 3, pp. 233-243.

[24] Pavlou, P. A. (2003). Consumer Acceptance of Electronic Commerce : Integrating Trust and Risk with the Technology Acceptance Model. International Journal of Electronic Commerce, 7(3), 101-134.

[25] Sekaran, U., \& Bougie, R. B. (2016). Research Methods For Business: A Skill Building Approach. ISBN: 9781119165552 . Wiley; $7^{\text {td }}$ Edition. 